DOI 10.37882/2223-2982.2021.06.09

\title{
ФОРМАТЫ КОРПОРАТИВНОГО ОБУЧЕНИЯ И ИХ ПРИМЕНЕНИЕ В ПРОЦЕССЕ РЕАЛИЗАЦИИ ОБРАЗОВАТЕЛЬНЫХ ПРОГРАММ СРЕДНЕГО ПРОФЕССИОНАЛЬНОГО ОБРАЗОВАНИЯ
}

\section{CORPORATE TRAINING FORMATS \\ AND THEIR APPLICATION \\ IN THE PROCESS OF IMPLEMENTING \\ EDUCATIONAL PROGRAMS \\ OF SECONDARY VOCATIONAL EDUCATION}

\section{Gerasimova \\ I. Volkova \\ A. Shelaumov}

Summary: This article is devoted to the search for new approaches to learning that would meet the new trends in the development of Russian society and would be able to meet the requirements of educational standards.

Keywords: corporate training, education, teacher, training.
Герасимова Ирина Евгеньевна

старший преподаватель, Институт транспорта, сервиса и туризма, Нижегородская область,

p.n. Воротынец

irinaGera1990@yandex.ru

Волкова Ирина Алексеевна

старший преподаватель, Институт транспорта, сервиса и туризма, Нижегородская область,

p.n. Воротынеи

volkova10011985@mail.ru

Шелаумов Александр Владимирович

старший преподаватель, Институт транспорта, сервиса и туризма, Нижегородская область,

p.n. Воротынец

shelaumov2013@yandex.ru

Аннотация: Эта статья посвящена поиску новых подходов к обучению, которые бы соответствовали новым тенденциям развития российского общества и смогли бы соответствовать требованиям образовательных стандартов.

Ключевые слова: корпоративное обучение, образование, педагог, обучение.

1. Как организовать учебный процесс, исходя из основных требований стандарта нового поколения?

2. Каким должно быть современное занятие?

3. Как найти новые подходы к обучению, которые бы соответствовали новым тенденциям развития российского общества?

Отвечая на первый вопрос, стоит отметить следующее:

Во-первых, при организации учебного процесса, нужно рационально распределять учебные часы по изучаемым разделам дисциплины, а последовательность тем, предлагаемых к изучению, должна быть направлена на качественное усвоение учебного материала.

Во-вторых, преподавателю необходимо иметь перечень практических занятий, которые направлены на процесс научного познания и теоретического обоснования профессиональных задач.

Немаловажным является вопрос об организации самостоятельной работы. Согласно требованиям федеральных государственных стандартов образования, к подготовке специалистов среднего звена, она должна быть направлена на закрепление умения поиска, накопления и обработки научной информации. 
Таблица 1.

«Форматы корпоративного обучения и их практическая реализация в образовательном процессе»

\begin{tabular}{|c|c|}
\hline Формат корпоративного обучения & Практическая реализация в образовательном процессе \\
\hline Метод Shadowing & Данный метод можно активно применять в обучении школьников и студентов, для усвоения иностранных языков \\
\hline Метод Secondment & $\begin{array}{l}\text { В системе образования - этот метод еще только начинает развиваться, институты и университеты РФ стараются } \\
\text { отправлять студентов в зарубежные «командировки» для получения знаний и опыта в той сфере, в которой они } \\
\text { обучаются. }\end{array}$ \\
\hline Метод Buddying & $\begin{array}{l}\text { Этот метод отдаленно можно сравнить с тьютерством. В данное время тьютеры- это редкое явление, но с развити- } \\
\text { ем технологий и появлением новых стандартов-эти методы могут стать основополагающими в учебном процессе }\end{array}$ \\
\hline Метафорическая игра & $\begin{array}{l}\text { Использование такой формы обучения помогает активизировать творческие способности участников, дает воз- } \\
\text { можность по-новому взглянуть на профессиональную ситуацию и изменить сложившиеся стереотипы. Метафори- } \\
\text { ческая игра способствует развитию креативности студентов; снижению тревожности участников по поводу реше- } \\
\text { ния той или иной проблемы; побуждению участников к самостоятельности }\end{array}$ \\
\hline Коучинг & $\begin{array}{l}\text { Используя коучинг, педагог помогает ребенку понять свои возможности и ресурсы, определить цели, превратив } \\
\text { проблемы в задачи. В отличие от традиционного образования, они помогают учащимся размышлять, а не без- } \\
\text { думно заучивать пустые факты и формулы. }\end{array}$ \\
\hline Обучение в рабочих группах & $\begin{array}{l}\text { Перед образовательными учреждениями, стоит задача научить своего выпускника умению общаться, работать в } \\
\text { коллективе, высказывать свою точку зрения и уметь ее аргументировать. } \\
\text { Использование на занятиях групповых форм работы может помочь ре шить эти задачи. Эти формы работы под- } \\
\text { разумевают создание таких условий, в рамках которых ученики активно взаимодействуют друг с другом. }\end{array}$ \\
\hline Кружок качества & $\begin{array}{l}\text { Данный метод можно использовать для выявления проблем в сфере образования, которые негативно влияют на } \\
\text { процесс обучения. }\end{array}$ \\
\hline Менторинг & $\begin{array}{l}\text { Данный метод используется в образовательных организациях и одной из важнейших задач наставника является } \\
\text { организация профессиональной адаптации молодого педагога к учебно-воспитательной среде. }\end{array}$ \\
\hline Иммерсивное обучение & Новый подход в мире образования: он не только делает процесс усвоения знаний более наглядным и зрелищным \\
\hline Сторителлинг & Это отличный способ разнообразить занятия, чтобы найти подход и заинтересовать любого ребенка. \\
\hline
\end{tabular}

В-третьих, преподаватель обязан предусмотреть активные и интерактивные формы проведения учебных занятий, а также современные методы и средства обучения, потому что использование активных педагогических технологий на занятиях способствует самостоятельной оценке своей деятельности учащимися, и это дает возможность говорить о формировании сознательных, активных, конструктивных личностей.

Отвечая на второй вопрос, стоит отметить что, развитие любознательности каждого студента, интереса к познавательной деятельности является важной и необходимой задачей, стоящей перед преподавателем.

При осуществлении образовательного процесса педагог должен использовать различные формы проведения занятий: дискуссии, «круглые столы», различные деловые и ролевые игры. Также стоит проводить коллоквиумы и викторины, и давать студентам творческие задания, которые будут направленны на формирование их самостоятельной деятельности.

Также преподавателю необходимо проводить открытые занятия со студентами для формирования у них системы базовых ценностей на основе осмысления обще- ственного развития, осознания уникальности каждой личности, раскрывающейся полностью только в обществе и через общество.

При ответе на третий вопрос, стоит обратить внимание на новые виды и форматы обучения.

Одним из таких новых подходов к обучению можно увидеть в применении в образовательном процессе студентов одного из форматов корпоративного обучения (таблица 1).

Делая вывод, можно сказать, что использование форматов корпоративного обучения в образовательном процессе студентов СПО и ВО способно совершить революцию в мире образования: - каждому педагогу предстоит переосмыслить новые реалии педагогической деятельности и образования в целом, переосмыслить профессию учителя и педагога, проявить творческий подход в формулировании и решении научно-педагогических и научно-методических задач, и соответственно, внести коррективы в свою повседневную педагогическую практику, а про студентов можно будет говорить как о сформированных, сознательных, активных, конструктивных личностях. 


\section{ЛИТЕРАТУРА}

1. Гедграфова Л.М. Тьюторское сопровождение студентов высших учебных заведений: сравнительный анализ зарубежной и российской практики http://irbis.gnpbu.ru/Aref_2014/Gedgrafova_L_M_2014.pdf

2. Конти Т. Будущее качества. (тандарты и качество/ Т. Конти. - М.: Европейское качество, 2000. - 335с.

3. Резник С.Д., Джевицкая Е.С. 0 повышении роли и механизмах подготовки научно-педагогических кадров в высшем учебном заведении [Текст]/ С.Д.Резник, Е.С. Джевицкая// Гуманитарные научные исследования. 2014, №12-1 (40). - С. 125-135.

4. Шамин А.Е., Касимова Ж.В. Особенности предоставления образовательных услуг в региональных вузах // Вестник НГИэИ. 2018. № 10 (89). С. 119-134.

○ Герасимова Ирина Евгеньевна (irinaGera1990@yandex.ru), Волкова Ирина Алексеевна (volkova10011985@mail.ru),
Шелаумов Александр Владимирович (shelaumov2013@yandex.ru).
Журнал «Современная наука: актуальные проблемы теории и практики»

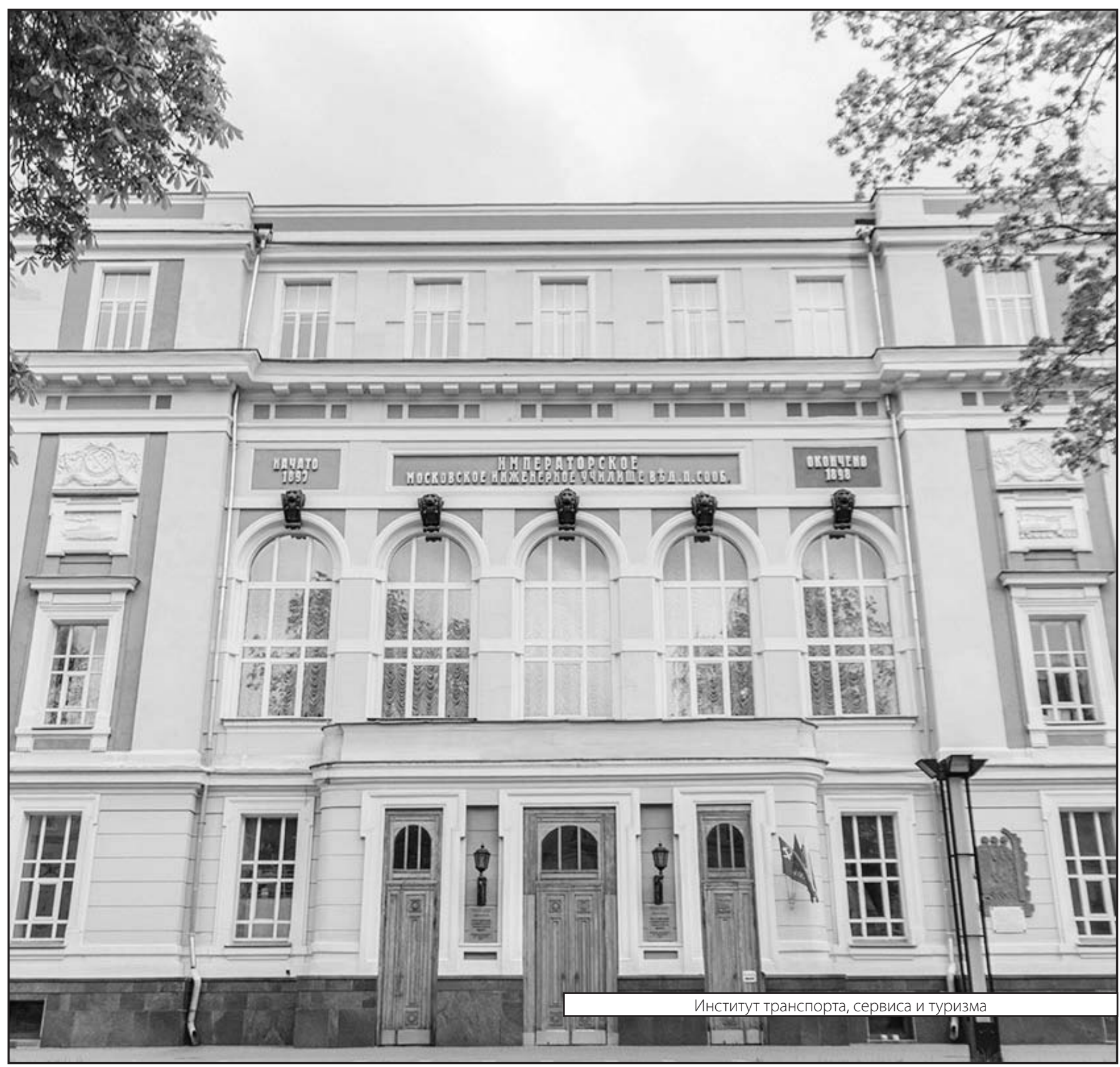

